Effect of Special Allocation Funds (DAK), Capital Expenditures, and Investment on Economic Growth in the Sulawesi Region
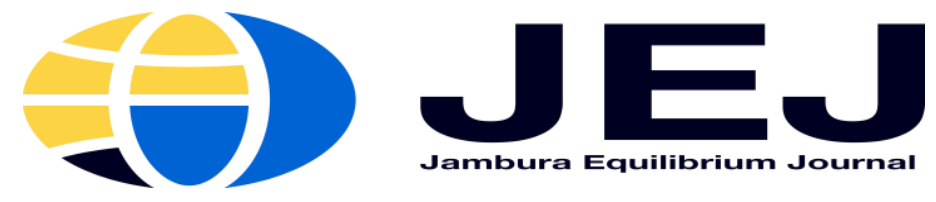

Volume 1. Issue 1. January 2019

P-ISSN 2655-9110

http://ejurnal.ung.ac.id/index.php/equij

\title{
Effect of Special Allocation Funds (DAK), Capital Expenditures, and Investment on Economic Growth in the Sulawesi Region
}

Fera Nur Ariyani Ibrahim ${ }^{1}$, Irawati Abdul ${ }^{2}$

Faculty of Economics, Gorontalo State University

Faculty of Economics, Gorontalo State University

Abstract. This study aims to analyze the effect of Special Allocation Funds, Capital Expenditures and Investment on Economic growth in the Sulawesi region. The data used are secondary data obtained from Simreg Bappenas and the Central Statistics Agency during 2007-2016. The unit of analysis is 6 provinces in the Sulawesi region. This study uses a panel data regression model with the Random Effect Model (REM) method. The results of this study indicate that, $(i)$ the Special Allocation Fund has a negative and significant effect on economic growth in the Sulawesi region. (ii) Capital expenditure shows a positive and significant influence on economic growth in the Sulawesi region. (iii) Investment shows a positive and significant influence on economic growth in the Sulawesi region.

Keywords: Special Allocation Funds, Capital Expenditures, Investment, Economic Growth, Random Effect Model (REM).

The role of the government as a distributor of development is very strategic in supporting the improvement of community welfare and economic growth in the region. Economic growth is an important component for the central government and local government. Economic growth encourages local governments to carry out economic development by managing existing resources and forming a partnership pattern with communities to create new jobs that will influence the development of activities in the area. Economic growth is defined as a process that causes per capita income of a country's population to increase in the long run. The economic growth of a region is generally shown by the GDP rate. The rate of growth of several sectors in each district / city varies greatly depending on the characteristics of the sectors in the city. High and sustainable economic growth is needed to be able to achieve an increase in community welfare, in addition it also requires relatively large capital to be used 
Effect of Special Allocation Funds (DAK), Capital Expenditures, and Investment on Economic Growth in the Sulawesi Region

to strengthen infrastructure, both physically and socially.

Economic growth in Indonesia is not independent of changes in the world economic situation. One of the major events in the past decade was the global financial crisis in 2008. The 2008 financial crisis first appeared in the United States and Britain triggered by speculation of property and inaccurate credit ratings that caused the collapse of several international financial institutions, crisis conditions this spread to other countries including Indonesia. The consequences of the financial crisis are always painstaking with macroeconomic indicators, especially economic growth. This was strengthened by the experience of the global crisis in 1997-1998 which caused negative economic growth in countries experiencing crisis. To prevent the wider impact of the 2008 crisis, the Indonesian government relaxed fiscal policy with a fiscal stimulus package.

Sulawesi is the largest and most important island in the Wallace region, a unique region in the world. Sulawesi Island consists of 6 provinces which have different backgrounds between regions. This difference is in the form of natural, social, economic, and natural resources characteristics whose distribution differs in each region. These differences become obstacles in the even distribution of economic development in several regions that have abundant natural resources. Sulawesi is one of the islands whose economic growth rate has always increased.

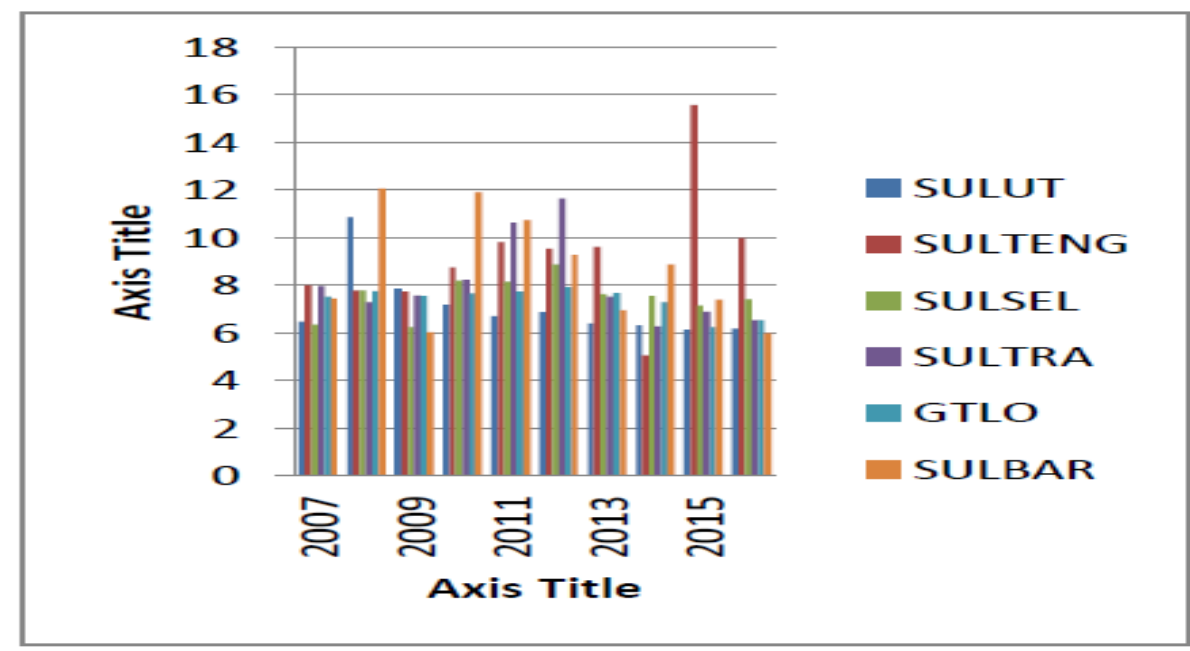

Figure 1. Regional Economic Growth in Sulawesi in 2007-2016 (Per Percent) 


\section{(Source: Central Bureau of Statistics and Simreg Bappenas)}

In figure 1, economic growth seen from GRDP on the basis of 2010 constant prices in 2007-2016 shows conditions that tend to rise and fall. The data above shows that in 2016 the highest economic growth was achieved by Central Sulawesi Province with a growth of $9.98 \%$. Affected by the increase in mining production, both metal (mikel) and gas are also followed in the processing industry. While the lowest growth rate is West Sulawesi Province with only reaching $5.97 \%$. The slowing down of economic growth in West Sulawesi was caused by several business sectors which experienced a sharp decline.

Special Allocation Funds (SAF) or Dana Alokasi Khusus (DAK) are part of local government financial resources. DAK plays an important role in data, the dynamics of the construction of basic service facilities and infrastructure in the regions because in accordance with the principle of decentralization - responsibility for providing basic community services has been transferred to local governments. On the other hand the regional financial capacity is very limited and the quality of regional spending is still very low. Therefore, DAK is very important in its function to achieve economic growth.
Shifting the composition of spending is a logical effort by the local government in order to increase the level of public trust. This shift is aimed at increasing capital investment in the form of fixed assets, namely equipment, buildings, infrastructure, and other fixed prices. The higher level of investment capital is expected to be able to improve the quality of public services, because the fixed assets owned as a result of capital expenditure are the main prerequisite in providing public services by the local government. The regional government allocates funds in the form of a capital expenditure budget in the APBD to add fixed assets. Capital expenditure is regional government expenditure which has an important influence on the economic growth of a region. Increasing capital expenditure, will directly touch the increase in development. Allocation of Capital Expenditures is based on regional needs for facilities and infrastructure, both for the smooth implementation of government duties and for public facilities. Infrastructure expenditure is included in the government's capital expenditure section, namely budget expenditure for the acquisition of fixed assets and other assets that provide benefits 
Effect of Special Allocation Funds (DAK), Capital Expenditures, and Investment on Economic Growth in the Sulawesi Region

for more than one accounting period. The provision of a capital expenditure stimulus package in the form of infrastructure improvements is expected to provide fiscal multipliers to anticipate the broader impact of the 2008 economic crisis.

Some economists view that the formation of investment is an important factor that is responsible for the economic growth of a country. When an entrepreneur or individual or government invests, there is a certain amount of capital invested or issued, or there are a number of purchases of goods that are not consumed, but are used for production, so as to produce goods and services in the future. Decentralization of development as a result of regional autonomy policies has consequences for the disparity in the implementation and results of development in each province. Each province will have its own strategy in building its area in accordance with its capabilities and potential. An area will develop dynamically if the investment spent is far greater than the depreciation value of its production factors, it will tend to experience a stagnant economy. Stagnation is an economic condition with a slow and even zero growth rate. development in each province will be different, especially policies in the field of economic development (investment and economic growth), but the ultimate goal is the same, namely improving people's welfare.

\section{METHODS}

The data used in this study is secondary data obtained from the Central Statistics Agency and the Registration Management Information System (Simreg Bappenas) during the period 2007-2016. This study uses quantitative methods.

\section{RESULTS}

Regression Analysis Results 
Effect of Special Allocation Funds (DAK), Capital Expenditures, and Investment on Economic Growth in the Sulawesi Region

Table 1. Result

\begin{tabular}{|c|c|c|c|c|}
\hline Variable & $\begin{array}{l}\text { Ceofficie } \\
\text { nt }\end{array}$ & $\begin{array}{l}\text { Std. } \\
\text { Error }\end{array}$ & $\begin{array}{c}\mathrm{t}- \\
\mathrm{C} \\
\mathrm{C}\end{array}$ & Prob. \\
\hline c & $\begin{array}{l}17.2600 \\
9\end{array}$ & $\begin{array}{l}1.9455 \\
54\end{array}$ & $\begin{array}{l}8.8715 \\
55\end{array}$ & $\begin{array}{l}0.000 \\
0\end{array}$ \\
\hline LOG(DAK?) & O. 16242 & $\begin{array}{l}0.0647 \\
92\end{array}$ & $\begin{array}{l}2.5068 \\
98\end{array}$ & $\frac{0.016}{7}$ \\
\hline LOG(BM?) & 0.20875 & $\begin{array}{l}0.0818 \\
73\end{array}$ & $\begin{array}{l}2.5497 \\
81\end{array}$ & ${ }_{1}^{0.015}$ \\
\hline $\begin{array}{l}\text { LOG(INVES } \\
\text { T?) }\end{array}$ & $\begin{array}{l}0.07119 \\
3\end{array}$ & $\begin{array}{l}0.0530 \\
0.0\end{array}$ & $\begin{array}{l}1.3432 \\
55\end{array}$ & $\begin{array}{l}0.187 \\
4\end{array}$ \\
\hline R-squared & 0.60159 & \multirow{3}{*}{\multicolumn{2}{|c|}{$\begin{array}{l}\text { Mean dependent } \\
\text { var } \\
\text { S.D. dependent } \\
\text { var } \\
\text { Sum squared } \\
\text { resid } \\
\text { Durbin-Watson } \\
\text { stat }\end{array}$}} & $\begin{array}{l}17.81 \\
763\end{array}$ \\
\hline $\begin{array}{l}\text { Adjusted R- } \\
\text { squared } \\
\text { S.E. of } \\
\text { regression } \\
\text { F-statistic }\end{array}$ & $\begin{array}{l}0.47238 \\
6 \\
0.31583 \\
9 \\
4.65590\end{array}$ & & & $\begin{array}{l}0.434 \\
817 \\
3.690 \\
898 \\
0.408 \\
0.58\end{array}$ \\
\hline $\begin{array}{l}\text { Prob(F- } \\
\text { statistic) }\end{array}$ & $\begin{array}{l}0.00014 \\
4\end{array}$ & & & \\
\hline
\end{tabular}

Source: Data Processing Results (Eviews 9), 2018

From the results of the estimation of economic growth models, it can be seen that special allocation funds negatively affect economic growth, each increase in the Special Allocation Fund by $1 \%$ will reduce economic growth by 0.162 percent. Meanwhile other variables namely Capital Expenditures have a positive influence on economic growth, each increase in capital expenditure by $1 \%$ will increase economic growth by 0.208 percent. Investment Variables have a positive influence on economic growth, each increase in investment by $10 \%$ will increase economic growth by 0.071 percent. Meanwhile, without being influenced by any variable, economic growth is worth 17.26 percent during 2007-2016 in 6 Sulawesi Region Provinces.

\section{DISCUSSION}

In general, the estimation results of the Special Allocation Fund model, capital expenditure, and investment in economic growth are quite good results. Based on the goodness off fit criteria where the adjusted $\mathrm{R}$-square value of $0.601 \%$ variation in changes in the value of economic growth can be explained by the variables of Special Allocation Funds, Capital Expenditures, and Investment. Similarly, the F test shows that the independent variables have a significant effect on economic growth in the provinces of North Sulawesi, Central 
Sulawesi, South Sulawesi, Southeast Sulawesi, Gorontalo and West Sulawesi from 2007-2016.

The initial findings in this study were that special allocation funds showed quite interesting signs, namely negative. Given the results of relevant study studies that show consistency with the findings in this study. Most studies on the effect of special allocation funds on economic growth have a negative effect. This is in accordance with research by Andri Widianto, Erni Unggul Sedya Utami, Asrofi Langgeng (2016) that the Special Allocation Fund has a negative effect. According to Ni Wayan and I Dewa Gede (2017) the Special Allocation Fund has a negative effect on economic growth. This is due to the fact that DAK is mostly allocated for education and health infrastructure which may not be the priority of the relevant regional government in the current year. DAK is not directly related to factors that directly encourage economic growth such as roads and bridges. The findings of this study are consistent with the research conducted by previous researchers as carried out by Andri Widianto, Erni Unggul Sedya Utami, Asrofi Langgeng Nurmansyah (2016) which shows the results of the special allocation fund negatively affecting economic growth. This is because special allocation funds provided by the central government are less optimized to share activities in sectors related to economic growth, such as the industrial and trade sectors, service sectors, and other sectors so that they are unable to increase economic productivity and ultimately cannot affect regional economic growth.

These results are not in accordance with the research hypothesis, where the Special Allocation Fund has a positive and significant effect on economic growth in the Sulawesi region not in accordance with the results of the study, this means the research hypothesis is rejected based on the regression results. Capital expenditure shows a positive and significant sign of economic growth. This is in accordance with previous research by Eunike Elisabeth Bawuno, Josep Bintang Kalangi and Jacline I. Sumual (2015) which shows that capital expenditure has a positive effect and is statistically significant for economic growth. Based on the regression results show that Capital Expenditures (BM) during the observation period is a positive and significant effect on economic growth in the Sulawesi region. Capital expenditure is an important matter for a region 
especially in carrying out its economic development in order to reduce public consumption of foreign products which can reduce the level of savings created in the future. But this research is not in line with the research conducted by Ni Wayan and I Dewa Gede (2017), namely capital expenditure has a negative effect on economic growth. The results of this study are in accordance with the existing hypothesis, which states that capital expenditure has a positive and significant effect on economic growth. The investment variable in this study shows a positive and significant sign. This is in accordance with the theory of Harrod-Domar in Arsyad (2010: 80-85) who developed Keynes's theory by giving a key role to investment in the process of economic growth, especially regarding the dual nature of investment. First, investment creates income (an impact of investment demand), and second, investment increases the production capacity of the economy by increasing the stock of capital (an impact of investment offers). The results of this study are also in accordance with the research conducted by Mutia Sari (2016) which shows that investment has a positive and significant effect on economic growth. The results of this study are in accordance with the existing hypothesis, which states that investment has a positive and significant effect on economic growth.

\section{CONCLUSION}

1. Special Allocation Funds have a negative and significant effect on economic growth in provinces in the Sulawesi region. Thus, any increase in the Special Allocation Fund will reduce economic growth. The higher the amount of special allocation funds, it will be expected to improve economic growth in each province in the Sulawesi region.

2. Capital expenditure has a positive and significant effect on economic growth in the Sulawesi region. Every increase in capital expenditure will increase economic growth. Productive spending and direct contact with the public interest will stimulate the economy to create new jobs so that it will absorb economic growth.

3. Investment has a positive and significant effect on economic growth. It will increase economic growth. Any increase in investment will increase rapid growth, because every economy must save and invest as much as possible part of its GNP. 
Effect of Special Allocation Funds (DAK), Capital Expenditures, and Investment on Economic Growth in the Sulawesi Region

\section{REFERENCES}

Alfiat, Nur Muhammad (2015), Analisis Pengaruh Pengeluaran Pemerintah Terhadap Struktur Ekonomi di Provinsi Sulawesi Tenggara. Jurnal Ekonomi Pembangunan FE-Unhalu Volume XVI Tahun 8, Desember 2015 hal 20-26.

Anasmen (2009), Pengaruh Belanja Modal Pemerintah terhadap pertumbuhan ekonomi di Provinsi Sumatera Barat (20002006).Tesis Fakultas Ekonomi, Program Studi Perencanaan dan Kebijakan Publik Kekhususan ekonomi keuangan Negara dan Daerah Depok, November 2009. Hal 17.

Asdar, (2012). Analisis Pengaruh Dana Perimbangan terhadap kemiskinan di Sulawesi Selatan periode 2001-2010. Skripsi Jurusan Ilmu Ekonomi Fakultas Ekonomi dan Bisnis Universitas Hasanuddin Makassar, 2012. Hal 26-27.

Badan Pusat Statistik. (2007-2016). Sulawesi Utara dalam Angka 2007-2016. Sulawesi Utara: Badan Pusat Statistik.

(2007-2016).

Sulawesi Tengah dalam Angka 2007-2016. Sulawesi Tengah: Badan Pusat Statistik.

(2007-2016).

Sulawesi Selatan dalam Angka 2007-2016. Sulawesi Selatan: Badan Pusat Statistik.

Sulawesi Tenggara dalam Angka
2007-2016. Sulawesi Tenggara:

Badan Pusat Statistik. Badan

Pusat Statistik. (2007-2016). Gorontalo dalam Angka 20072016. Gorontalo: Badan Pusat Statistik.

(2007- 2016).

Sulawesi Barat dalam Angka 2007-2016. Sulawesi Barat : Badan Pusat Statistik.

Dossantos, aquina cardoso. 2015. Faktor-faktor yang Mempengaruhi pertumbuhan ekonomi di Indonesia Tahun 1986-2013. Skripsi fakultas Ekonomi Universitas Atma Jaya Yogyakarta. Hal 23-24.

Elisabeth, eunike. Bintang, joseph. Summual, Jacline. (2015). Pengaruh Investasi dan Tenaga Kerja terhadap pertumbuhan Ekonomi di Kota Manado (studi pada Kota Manado tahun 20032012). Jurnal berkala efisiensi. Vol.15. No.4. Hal.252.

Kasyati, (2015). Pengaruh Dana Alokasi Umum, Dana Alokasi Khusus, Pendapatan Asli Daerah, pertumbuhan ekonomi, dan bagi hasil, dan kemandirian fiscal terhadap pengalokasian anggaran belanja modal. (Studi Kasus Pada Pemerintah Kabupaten/Kota Di Jawa Tengah). Skripsi Jurusan Akuntansi Fakultas Ekonomi Universitas Negeri Semarang. Hal 31-32.

Mutiah,2017. Pengaruh Pendapatan Asli Daerah, Dana Bagi Hasil, Dana Alokasi Umum dan Dana Alokasi Khusus pada 
Pertumbuhan Ekonomi Daerah. (Studi Empiris di 33 Provinsi di Indonesia Tahun 2011-2014). Research Journal Of Finance and Accounting. Vol.8.2017. Hal 107.

Rahayu, Sri endang. (2011), Analisis Pengaruh Pengeluaran Terhadap Pertumbuhan Ekonomi di Sumatera Utara, Jurnal Manajemen \& Bisnis Vol 11 No.02 Oktober 2011. Hal 129130.

Ratnadewi, Niwayan. Dharma saputra, I dewa gede. (2017). Pengaruh Pendapatan Asli daerah, Dana Alokasi Umum, Dana Alokasi Khusus dan Belanja Modal terhadap pertumbuhan Ekonomi. E-Jurnal Akuntasi Universitas Udayana Vol 18.3. Hal 1747.

Sari, Mutia. (2016). Pengaruh Investasi, Tenaga Kerja dan Pengeluaran Pemerintah terhadap pertumbuhan Ekonomi di Indonesia. Jurnal Ekonomi dan Kebijakan Publik 2016, Vol 3 Hal 113.
Sulistiawati,Rini.(2012). Pengaruh investasi terhadap pertumbuhan Ekonomi dan penyerapan tenaga kerja serta kesejahteraan masyarakat di Provinsi di Indonesia. Jurnal ekonomi bisnis dan kewirausahaan 2012, vol 3,Hal 29-50.

Suhendra, Sulindawati, Adiputra (2015), Pengaruh Dana Alokasi Umum (DAU), Dana Alokasi Khusus (DAK), dan Belanja Pemeliharaan terhadap Pengalokasian Anggaran Belanja Modal Pada Kabupatn/kota di Bali Periode 2009-2013. Journal S1 Ak Universitas Pendidikan Ganesha Jurusan Akuntansi Program S1. Vol.3. Hal 30.

Sial, Maqbool Hussain. Hashmi, Maaida Husain. Anwar, Sofia.(2010). Peran Investasi Pada Pertumbuhan Ekonomi di Pakistan. World Academy of Science, Engineering and Technology 66 2010. Hal 5.

Taha, Yulian Rinawaty. Nursini. Agussalim. (2016). Pengaruh Dana Perimbangan Terhadap Pertumbuhan Ekonomi di Provinsi Sulawesi Tengah. Hal 15. 